Original Article

\title{
The antagonistic activity of the synbiotic containing Lactobacillus acidophilus and pineapple residue FOS against pathogenic bacteria
}

\author{
A atividade antagônica do simbiótico contendo Lactobacillus acidophilus e resíduo de \\ abacaxi FOS contra bactérias patogênicas
}

\author{
A. A. Ibrahemª, S. G. Al-Shawia* (1) and W. K. A. Al-Temimia (1) \\ aBasrah University, Agriculture College, Food Science Department, Basrah, Iraq
}

\begin{abstract}
Fructooligosaccharide is used widely in many foods and pharmaceutical industries and produced by using different ways such as extracting it from plants or producing it by using plants and microorganisms' enzymes. In a previous study, we extracted Fructosyltransferase (Ftase) enzyme from pineapple residue and produced FOS. In this study, we measured the antagonistic activity of two synbiotics, the first synbiotic containing Lactobacillus acidophilus and the produced FOS, the second synbiotic containing Lactobacillus acidophilus and standard FOS, against pathogenic bacteria (P. aeruginosa, E. coli, S. aureus and B cereus). The results showed that the antagonistic activity of both synbiotic types was very close, as there were no significant differences between them except in the antagonistic activity against $S$. aureus, there was a significant difference between the synbiotic containing the standard FOS, which was the highest in its antagonistic activity compared to the synbiotic containing the produced FOS in this study. The activity of the fructooligosaccharide (FOS) extracted from pineapple residue was evident in enhancing the activity of the probiotic bacteria ( $L$. acidophilus), which had a major role in the production of acids and compounds that inhibited the pathogenic bacteria. The diameters of inhibition areas in the current study ranged between 19.33-28 $\mathrm{mm}$, and E. coli was more susceptible to inhibition, followed by S. aureus, P. aeruginosa, and B. cereus, respectively.
\end{abstract}

Keywords: fructo-oligosaccharide, synbiotic, antagonistic activity, pineapple residue.

\begin{abstract}
Resumo
O fruto-oligossacarídeo (FOS) é amplamente utilizado em muitos alimentos e indústrias farmacêuticas, e é produzido por meio de diferentes maneiras, como extraí-lo de plantas ou produzi-lo usando enzimas de plantas e microrganismos. Em um estudo anterior, extraímos a enzima frutosiltransferase (Ftase) do resíduo de abacaxi e produzimos FOS. Neste estudo, medimos a atividade antagônica de dois simbióticos: o primeiro simbiótico contendo Lactobacillus acidophilus e o FOS produzido, e o segundo simbiótico contendo Lactobacillus acidophilus e o FOS padrão, contra bactérias patogênicas ( $P$. aeruginosa, E. coli, S. aureus e B. cereus). Os resultados mostraram que a atividade antagônica de ambos os tipos simbióticos foi muito próxima, pois não houve diferenças significativas entre eles, exceto na atividade antagônica contra S. aureus, em que houve uma diferença significativa entre o simbiótico contendo o FOS padrão, que foi o mais alto em sua atividade antagônica, em comparação com o simbiótico contendo o FOS produzido neste estudo. A atividade do fruto-oligossacarídeo (FOS) extraído do resíduo de abacaxi ficou evidente no aumento da atividade da bactéria probiótica (L. acidophilus), que teve papel importante na produção de ácidos e compostos inibidores das bactérias patogênicas. Os diâmetros das áreas de inibição no estudo atual variaram entre 19,33 e 28 mm, e E. coli foi mais suscetível à inibição, seguida por S. aureus, P. aeruginosa e B. cereus, respectivamente.
\end{abstract}

Palavras-chave: fruto-oligossacarídeo, simbiótica, atividade antagônica, resíduo de abacaxi.

\section{Introduction}

Fructo-oligosaccharide (FOS) is the most common type of prebiotic. It is found in some foods such as bananas, wheat, honey, onions, and tomatoes, and unlike probiotic bacteria, prebiotics are not destroyed when cooked. FOS is also a high-value product with a rapidly expanding market. FOS is a fructan of the inulin family that is widely used in functional foods. It's one of the most well-known oligosaccharides linked to bifidogenesis. FOS is a lowcalorie, noncariogenic material that helps people manage their cholesterol and lipid profiles. It is highly hygroscopic

*e-mail: sarmad.mohammed@uobasrah.edu.iq

Received: November 16, 2021 - Accepted: December 3, 2021 
and water soluble (Gibson and Roberfroid, 1995; Gibson et al., 1995; Roberfroid, 2001; Duggan et al., 2002; Fan et al., 2021; Wongkrasant et al., 2020; Andermann et al., 2021; Zhang et al., 2021). The most common prebiotic foods include soybeans, artichokes, oats, honey, berries, asparagus, many fruits, and goat's milk (Farnworth, 2008).

Mixing probiotics and prebiotics in the new world is concerned with health (Martins et al., 2010; Maftei, 2019; Morovic and Budinoff, 2021; Shahzad et al., 2023). The preparation of a synbiotic mixture was never successful without testing of dose amount, compatibility, or type of prebiotic sugar (or non-digestible sugars) with the probiotic strain. The combination of prebiotics and probiotics has good synergistic effects if they are mixed after studies involving the growth rate and fermentation profile of different probiotic strains in the presence of oligosaccharides. The added prebiotics not only stimulate similar probiotic strains collectively, but also encourage the growth of existing strains of beneficial bacteria in the colon (Spring et al., 2000; Sims et al., 2004).

To build a synbiotic system (probiotic + prebiotic) we need to find a vital substance that is not digested as it passes through the human gut. Its beneficial effect on human health should be noted as a selective stimulate for the growth and activity of probiotic cultures. Dietary prebiotics, which are non-digestible food ingredients, benefit host health by promoting the growth of probiotics, which are live microorganisms that can help restore and/ or improve gut flora. When digestive/absorptive resistance prebiotics enter the colon from the small intestine, gut microbes ferment them, producing nutrients and other essential substances like antibiotics, anti-carcinogens, and inhibitors of bacterial toxin production, among other things. Probiotics should be supplemented with appropriate prebiotics, collectively known as synbiotics, in order for them to reach their full potential (Gibson and Roberfroid, 1995; Hugenholtz and Smid, 2002).

The blend of probiotics and prebiotics is alluded to as synbiotic which is a combination of probiotics and prebiotics that positively influence the host by improving the viability and application of live microbial nutritional supplements in the digestive system by stimulate the growth selectively and / or by metabolism activation of the beneficial bacteria and thus enhance the host health (Gibson and Roberfroid, 1995). Synbiotic have been shown to confer health benefits beyond those of any of them alone. Rowland et al. (1998) reported the positive effect of synbiotic in reducing the number of colitis infections, as well as colon carcinogenesis in mice (Gallaher and Khil, 1999). It was found that diarrhea associated with antibiotics could be prevented by the combined application of Lactobacillus sporogenes and FOS in children (La Rosa et al., 2003). The synbiotic combination of $L$. paracasei and maltodextrin had a clear effect in reducing the growth of $E$. coli in pig's jejunum. This synbiotic combination resulted in an increase in lactobacilli and bifidobacteria and decreased clostridia and enterobacteria (Bomba et al., 2002). On the other hand, Anderson et al. (2004) didn't find any improvement in bowel barrier function in patients following treatment with synbiotic.
In vitro growth inhibition testing is a useful procedure that can be used to support product selection for further investigation, for example, in clinical trials. Synbiotic may have an extra benefit over pure probiotics, as their prebiotic part gives a wellspring of energy, which may uphold the expansion of their probiotic segments.

There was a rapid decrease in the numbers of pathogenic bacteria from Escherichia coli and C. perfringens in the fermentation medium when adding oligofructose to pure cultures of Bifidobacterium infantis (Wang and Gibson, 1993). Also, past examinations recognized LAB strains that could use inulin or FOS in a culture medium and get more live cell numbers. For instance, Manderson et al. (2005) illustrated that the counts of cells from Bifidobacterium strains was $\log 8.63 \mathrm{cfu} / \mathrm{ml}$ in the MRS medium, within the existence of FOS after $24 \mathrm{~h}$. In another examination, it was found that L. acidophilus NIT200 and L. plantarum NIT202 could utilize FOS (Pan et al., 2009).

Klewicki and Klewicka (2004) showed that the inhibitory activity of $L$. acidophilus, $L$. casei, and L. paracasei in the presence of gal-xylitol as a carbonic source against the enteric bacteria Escherichia coli, Salmonella typhimurium, Shigella sonnei S, Enterobacter cloacae and Citrobacter freundi ranged between 1-5.6 mm, as the inhibition activity of $L$. acidophilus against the pathogenic bacteria was 4.3, 2.1, 1, 5.1 and $4.8 \mathrm{~mm}$, respectively. The inhibitory activity of the same bacteria in the presence of gal-erythritol as a carbonic source against the intestinal bacteria Escherichia coli, Salmonella typhimurium, Shigella sonnei S, Enterobacter cloacae and Citrobacter freundi ranged between 3.6-7.5 mm, whereas the inhibition activity of $L$. acidophilus against the pathogenic bacteria was 4.7, 5.9, 5.8, 6.7 and $6.2 \mathrm{~mm}$, respectively (Klewicki and Klewicka, 2004).

Watson et al. (2013) showed that the growth of Lactobacillus spp. in the presence of maltodextrin and inulin was weak compared to the effect induced by glucose. Similar behavior was observed by Iraporda et al. (2019) in terms of the effect of inulin. McLaughlin et al. (2015) also noted when using Maltodextrin, beta-glucan, or corn fibers as the carbon source for growing Lactobacillus spp. that the strains did not produce any growth or weaker growth than when glucose was used as the carbon source. Moreover, the researchers noted that inulin supports the growth ability of one of ten species of Lactobacillus spp. to a similar extent as glucose, which also indicates the dependent nature of the bacteria's ability to utilize carbohydrates (McLaughlin et al., 2015). The high prebiotic fermentation capacity of $L$. casei L1 providing bile salts and acidity resistance, as well as anti-bacterial activity (Tulumoğlu et al., 2018). Önal Darilmaz et al. (2019) illustrated an increased growth in Lactobacillus spp. in the presence of $5 \%(\mathrm{w} / \mathrm{v})$ of inulin compared to cultures conducted in the MRS medium in the presence of $2 \%(\mathrm{w} / \mathrm{v})$ glucose.

Although $L$. reuteri is known to produce a bacteriocin (reutrin) bound as antimicrobial against pathogens such as E. coli, it has shown a significant increase in the growth rate and inhibitory action against bacteria when using FOS as a sole source of carbon (Manning and Gibson, 2004; Bengmark, 2005).

Likotrafiti et al. (2015) and Kanjan and Hongpattarakere (2017) noticed an overall decrease in S. Typhimurium 
SA2093 cells in the presence of both inulin and the probiotic L. paracasei.

Additionally, Chaiyasut et al. (2017) also noted a significant decrease in Salmonella spp. in the presence of Lactobacillus spp. and inulin. The tested prebiotics Fructo-Oligosaccharide (FOS) and inulin improved the antimicrobial activity of the probiotic L. acidophilus, $L$. lactis and $L$. casei supernatants against gram positive $S$. aureus to a greater extent compared to the gram-negative E. coli, showing that the metabolites participated with the antimicrobial activity are different or act in different way (Stefania et al., 2017).

Among the species of Lactobacillus spp., including L. rhamnosus GG, L. casei L1, showed just inhibitory action to the cell-free supernatant when grown in MRS medium and when FOS and inulin were utilized as a carbon source, demonstrating that this strain produces antimicrobial materials, potentially bacteriocin. L. casei L1 showed more antimicrobial activity against E. coli, S. aureus and $P$. aeruginosa when cultivated with FOS compared to inulin (Tulumoğlu et al., 2018). The cell-free supernatant of $L$. casei $L 1$ with FOS gave antimicrobial activity against Gram-positive and Gram-negative pathogenic bacteria (Tulumoğlu et al., 2018).

When studying the inhibition of E. coli, S. typhimurium, and $C$. difficile in the laboratory, by using probiotics containing $S$. boulardii, all four pathogens were inhibited (Piatek et al., 2020). Similar inhibitors have been seen with a bacterial probiotic containing three various strains (Pen, $\mathrm{E} / \mathrm{N}$, and Oxy) of L. rhamnosus comparing with the current inhibition of these probiotics, the inhibitory impacts of the multi-cultures synbiotic complex, containing nine various strains of probiotic (6 Lactobacilli and 3 Bifidobacteria) and fructooligosaccharide, were significantly stronger. The highest inhibition was seen by the complex multi-strain synbiotic against all four tested pathogens (Piatek et al., 2019).

Piatek et al. (2020) studied the inhibitory activity of Saccharomyces boulardii, and probiotics (L. acidophilus, L. casei, L. paracasei, L. plantarum, L. rhamnosus GG, L. salivarius, B. bifidum, B. longum). B. lactis and mixtures of this bacterium with the fructo-oligosaccharide against $E$. coli EPEC, Shigella sonnei, S. typhimurium, K. pneumoniae, and C. difficile. The pathogenic bacterial inhibition was moderate by Sac. Boulardii and L. rhamnosus GG, and mediated by $L$. reuteri and $L$. rhamnosus, and strong by the synbiotic mixture. Inhibition's diameters ranged from 4-14.1 mm.

Laal-Kargar et al. (2020) showed the inhibitory efficacy of four strains of Lactobacillus bacteria in the existence of $0.3 \%$ sorbitol, ranose, trehalose, inulin, using the (well diffusion agar) method against Acinetobacter baumannii and Enterocoocus faecalis. The $L$. rhamnosus cell-free supernatant of and trehalose exhibited the highest inhibitory activity against $A$. baumannii $(28.8 \pm 2.1 \mathrm{~mm})$ and the cell-free supernatant of $L$. rhamnosus with all prebiotics used against E. faecalis $(29.8 \pm 0 \mathrm{~mm}$ ) compared to that of probiotics alone. Prebiotics could enhance the inhibitory effect of probiotics against Gram-negative A. baumannii higher than Gram-positive E. faecalis.

The inhibitory ability of a mixture of Lactobacillus spp., Including L. rhamnosus, L. paracasei, L. reuteri, L. plantarum, and $L$. pentosus differed towards the pathogenic bacteria. Where it was observed that the ability to reduce the number of pathogenic bacteria was dependent on the prebiotics used as a source of carbon in the culture, as well as the type of pathogenic bacteria. The strongest inhibitory activity against pathogenic bacteria was observed when using a co-culture in the presence of $2 \%(w / v)$ of inulin, which resulted in an overall decrease in Salmonella spp. counts and it became undetectable after $24 \mathrm{~h}$. of incubation. However, the number of $L$. monocytogenes was reduced from the $\log 7.29$ to the $\log 2.39$, which is a decrease of approximately $70 \%$ of the bacterial number. On the other hand, similar results were observed in the co-culture of the combination of probiotics L. monocytogenes in the presence of maltodextrin, as well as against S. Choleraesuis when apple pectin and beta-glucan were used as carbon sources. Moreover, the most vulnerable pathogenic bacteria to inhibitory activity were Salmonella spp., with the exception of co-cultures cultivated in the presence of apple pectin and beta-glucan, in which inhibition against $S$. Choleraesuis was weaker than against $L$. monocytogenes (Śliżewska and Chlebicz-Wójcik, 2020).

The objective of our study was to evaluate the antagonistic activity of the produced FOS (from pineapple residues) against pathogenic bacteria compared to the standard FOS, seeking about a potential good new source of FOS.

\section{Material and Methods}

\subsection{Probiotic bacteria}

Lactobacillus acidophilus was obtained from LGGTM (Finland).

\subsection{Prebiotic}

Fructo-oligosaccharides from chicory were obtained from SIGMA (USA).

\subsection{Pathogenic bacteria}

The pathogenic bacteria (Pseudomonas aeruginosa, Escherichia coli, Staphylococcus aureus and Bacillus cereus) were obtained from the laboratories of Food Science Department- Agriculture College - University of Basrah - Iraq.

\subsection{Preparation of probiotic cell-free supernatant with produced and standard prebiotic}

$10^{8} \mathrm{cfu} / \mathrm{ml}$ of probiotics (Lactobacillus acidophilus) were inoculated in $10 \mathrm{ml}$ of MRS broth medium prepared according to the ingredients of HiMedia MRS broth with the addition of $2 \%$ of FOS, once (the produced FOS) and once (the standard FOS) instead of glucose and incubated for 48 hours at $37^{\circ} \mathrm{C}$ under anaerobic conditions. Then, centrifugation was performed at $7000 \mathrm{rpm}$ for 20 minutes at $4{ }^{\circ} \mathrm{C}$, and the supernatant was filtered with a sterile Millipore filter. 


\subsection{Evaluation of synbiotic antagonistic activity against pathogenic bacteria}

To evaluate the antagonistic activity (for Synbiotic) of the probiotic Lactobacillus acidophilus with produced and standard (FOS) against pathogenic bacteria (Pseudomonas aeruginosa, Escherichia coli, Staphylococcus aureus, and Bacillus cereus), well diffusion agar was used.

\subsection{Well diffusion agar method}

The filtrated cell free supernatant of synbiotic cells was gathered and utilized in a well diffusion agar method, Mueller Hinton agar was used after its preparation and poured into dishes and left to harden. L-shape was used to spread the pathogenic bacterial culture on the agar surface. Then, the cork borer was used to make holes of $0.5 \mathrm{~cm}$ in diameter in the agar. The cell-free supernatant of the synbiotic was added to the holes and incubated at $37^{\circ} \mathrm{C}$ for $48 \mathrm{~h}$. After the incubation period, the growth inhibition area was estimated and compared with the control group.

\subsection{Statistical analysis}

The results were analyzed using SPSS (Statistical Package for Social Sciences) of 2019, and the results were compared using the least significant difference at the level of significance of 0.05 .

\section{Results and Discussion}

\subsection{Evaluation of synbiotic antagonistic activity against pathogenic bacteria}

Figure 1 shows the antagonistic activity of two types of synbiotic, the first synbiotic Lactobacillus acidophilus with standard FOS and the second synbiotic Lactobacillus acidophilus with the produced FOS in this study against pathogenic bacteria (P. aeruginosa, E. coli, S. aureus and $B$. cereus). The results show that the antagonistic activity of both synbiotic types was very close, as there were no significant differences between them except in the antagonistic activity against $S$. aureus, as there was a significant difference between the synbiotic containing the standard FOS, which was the highest in its antagonistic activity compared to the synbiotic containing the produced FOS in this study.

The activity of the fructo-oligosaccharide (FOS) extracted from pineapple residue was evident in enhancing the activity of the probiotic bacteria (L. acidophilus), which had a major role in the production of acids and compounds that inhibited the pathogenic bacteria. This is similar to what Manning and Gibson (2004) and Bengmark (2005) found when using only FOS as a carbon source with L. reuteri, which had a significant role in the growth of probiotic bacteria, and inhibition of $E$. coli. Also, the cell-free supernatant of the mixture of L. casei, inulin and FOS as a carbon source had good antimicrobial activity against $E$. coli, S. aureus and $P$. aeruginosa and had more antimicrobial activity against pathogenic bacteria when cultivated with FOS compared to inulin (Tulumoğlu et al., 2018). "FOSs" are a typical growth factor for lactic acid bacteria and are perhaps the most widely used fructo-oligosaccharide on the market (Bouhnik et al., 1999). As well as Pan et al. (2009) illustrated that $L$. acidophilus NIT200 and L. plantarum NIT202 could utilize FOS as carbon source.

The diameters of inhibition areas in the current study ranged between $19.33-28 \mathrm{~mm}$, and E. coli was more susceptible to inhibition, followed by $S$. aureus, P. aeruginosa, and B. cereus, respectively. These areas of inhibition are much bigger than what Piatek et al. (2020) found with different bacterial strains and FOS against E. coli EPEC, S. sonnei, S. typhimurium, K. pneumoniae, and C. difficile, as the inhibition diameters ranged between $4-14.1 \mathrm{~mm}$ and larger than what Klewicki and Klewicka (2004) found when using gal-xylitol and gal-erythritol as a carbon source with L. acidophilus, L. casei and L. paracasei bacteria against pathogenic bacteria, where the inhibition diameters ranged between $1-5.6 \mathrm{~mm}$, while study results were close to what Laal-Kargar et al. (2020) found, that the regions of inhibition were between $28.8-29.8 \mathrm{~mm}$ when trehalose was used with $L$. rhamnosus against $A$. baumannii as well as with all prebiotics used against $E$. faecalis, respectively.

\section{The antagonistic activity of synbiotics cell-free supernatant against pathogenic bacteria}

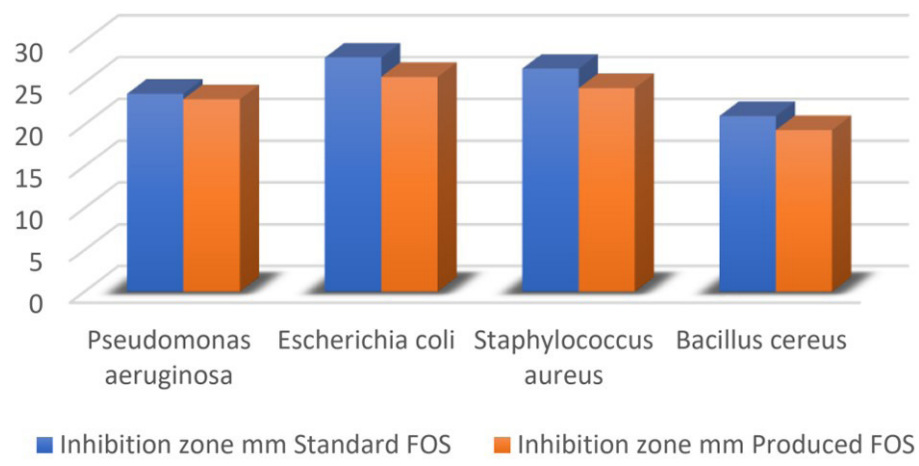

Figure 1. Antagonistic activity of synbiotic cell-free supernatant against pathogenic bacteria. 


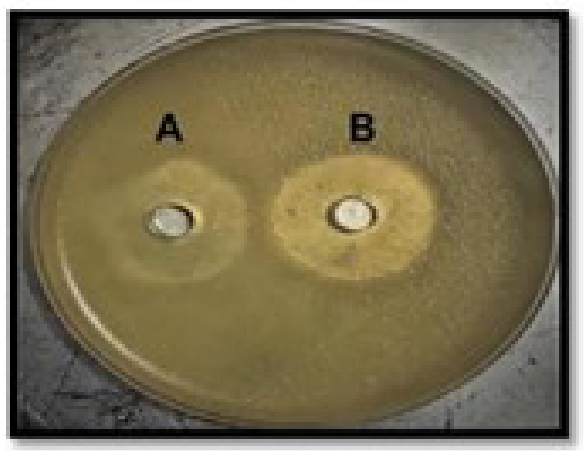

Escherichia coli

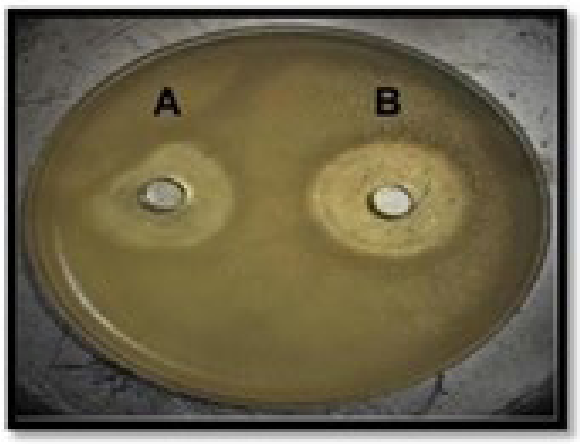

Staphylococcus aureus

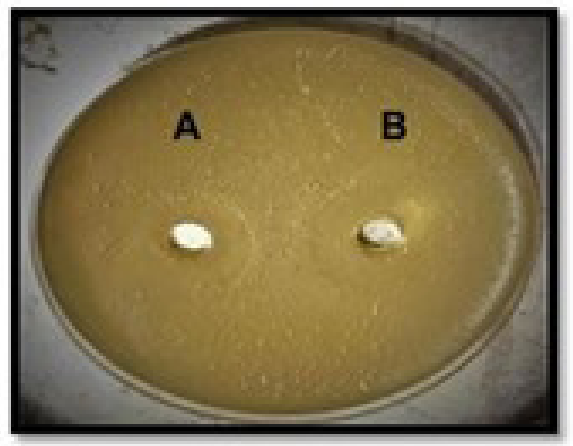

Bacillus cereus

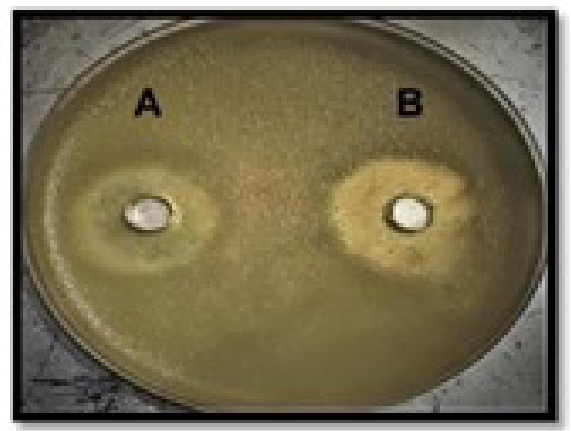

Pseudomonasaeruginosa

Figure 2. Photos of antagonistic activity of synbiotic cell-free supernatant against pathogenic bacteria. (A) L. acidophilus + Produced FOS; (B) L. acidophilus + Standard FOS.

The inhibition effect was comparable on gram negative and gram positively with little superiority in inhibition against gram negative bacteria, and this is in agreement with Laal-Kargar et al. (2020) who showed the possibility that prebiotics enhance the inhibitory effect of probiotics against gram negative $A$. baumannii bacteria higher than gram positive E. faecalis, while Stefania et al. (2017) found that the effect of inhibition by using FOS and inulin with $L$. acidophilus, L. lactis and $L$. casei against gram positive $S$. aureus was higher compared to the gram negative E. coli. The inhibitory activity of LAB bacteria results from its acid-forming capabilities. The formation of lactic and acetic acid from carbohydrates lowers the $\mathrm{pH}$ of the medium (Lee and Salminen, 1995), which inhibits the growth of many pathogenic microorganisms that contaminate food. Ethanol, acetaldehyde, and hydrogen peroxide were found in media containing different carbohydrates as the carbon source for lactic acid bacteria (Kandler, 1983; Vandenbergh, 1993).

The results of the antagonistic activity of synbiotics agreed with Wang and Gibson (1993) when using oligofructose with $B$. infantis, as there was an apparent inhibition or reduction of the pathogenic bacteria $E$. coli and C. perfringens in the fermentation medium. Study results did not agree with what Watson et al. (2013), McLaughlin et al.
(2015) and Iraporda et al. (2019) reported that the used prebiotics (maltodextrin, inulin, beta-glucan or corn fiber) did not improve the growth of probiotic bacteria when using as a carbon source. The present study agreed with the finding of Śliżewska and Chlebicz-Wójcik (2020), that $2 \%(w / v)$ of inulin was suitable with probiotic bacteria to induce significant inhibition against the pathogenic bacteria. Figure 2 illustrates the antagonistic activity area of synbiotic cell-free supernatant against pathogenic bacteria

\section{Conclusion}

Considering the obtained results, the produced FOS from pineapple residues was close in its antagonistic activity to the standard FOS against the tested pathogenic bacteria and that means pineapple residues is a good source for FOS that enhanced the growth of probiotic bacteria and its metabolites which inhibited the pathogenic bacteria.

\section{References}

ANDERMANN, T.M., FOULADI, F., TAMBURINI, F.B., SAHAF, B., TKACHENKO, E., GREENE, C., BUCKLEY, M.T., BROOKS, E.F., 
HEDLIN, H., ARAI, S., MACKALL, C.L., MIKLOS, D., NEGRIN, R.S. FODOR, A.A., REZVANI, A.R. and BHATT, A.S., 2021. A fructooligosaccharide prebiotic is well tolerated in adults undergoing allogeneic hematopoietic stem cell transplantation: a phase I dose-escalation trial. Transplantation and Cellular Therapy, vol. 27, no. 11, pp. 932.e1-932.e11. http://dx.doi.org/10.1016/j. jtct.2021.07.009. PMid:34274493.

ANDERSON, A.D.G., MCNAUGHT, C.E., JAIN, P.K. and MACFIE, J., 2004. Randomised clinical trial of synbiotic therapy in elective surgical patients. Gut, vol. 53, no. 2, pp. 241-245. http://dx.doi. org/10.1136/gut.2003.024620. PMid:14724157.

BENGMARK, S., 2005. Bioecologic control of the gastrointestinal tract: the role of flora and supplemented probiotics and synbiotics. Gastroenterology Clinics, vol. 34, no. 3, pp. 413-436. http://dx.doi.org/10.1016/j.gtc.2005.05.002. PMid:16084305.

BOMBA, A., NEMCOVA, R., GANCARCIKOVA, S., HERICH, R., GUBA, P. and MUDRONOVA, D., 2002. Improvement of the probiotic effect of micro-organisms by their combination with maltodextrins, fructo-oligosaccharides and polyunsaturated fatty acids. British Journal of Nutrition, vol. 88, suppl. 1, pp. S95-S99. http://dx.doi. org/10.1079/BJN2002634. PMid:12215187.

BOUHNIK, Y., VAHEDI, K., ACHOUR, L., ATTAR, A., SALFATI, J., POCHART, P., MARTEAU, P., FLOURIE, B., BORNET, F. and RAMBAUD, J.-C., 1999. Short-chain fructo-oligosaccharide administration dose-dependently increases fecal bifidobacteria in healthy humans. The Journal of Nutrition, vol. 129, no. 1, pp. 113-116. http://dx.doi.org/10.1093/jn/129.1.113. PMid:9915885.

CHAIYASUT, C., PATTANANANDECHA, T., SIRILUN, S., SUWANNALERT, P., PEERAJAN, S. and SIVAMARUTHI, B.S., 2017. Synbiotic preparation with lactic acid bacteria and inulin as a functional food: in vivo evaluation of microbial activities, and preneoplastic aberrant crypt foci. Food Science and Technology (Campinas), vol. 37, no. 2, pp. 328-336. http://dx.doi.org/10.1590/1678457x.26216.

DUGGAN, C., GANNON, J. and WALKER, W.A., 2002. Protective nutrients and functional foods for the gastrointestinal tract. The American Journal of Clinical Nutrition, vol. 75, no. 5, pp. 789808. http://dx.doi.org/10.1093/ajcn/75.5.789. PMid:11976152.

FAN, R., BURGHARDT, J.P., HUANG, J., XIONG, T. and CZERMAK, P., 2021. Purification of crude fructo-oligosaccharide preparations using probiotic bacteria for the selective fermentation of monosaccharide byproducts. Frontiers in Microbiology, vol. 11, pp. 620626. http://dx.doi.org/10.3389/fmicb.2020.620626. PMid:33584587.

FARNWORTH, E.R.T., 2008. Handbook of fermented functional foods. Boca Raton: CRC Press. http://dx.doi.org/10.1201/9781420053289.

GALLAHER, D.D. and KHIL, J., 1999. The effect of synbiotics on colon carcinogenesis in rats. The Journal of Nutrition, vol. 129, no. 7, suppl., pp. 1483S-1487S. http://dx.doi.org/10.1093/ jn/129.7.1483S. PMid:10395626.

GIBSON, G.R., BEATTY, E.R., WANG, X.I.N. and CUMMINGS, J.H., 1995. Selective stimulation of bifidobacteria in the human colon by oligofructose and inulin. Gastroenterology, vol. 108, no. 4, pp. 975-982. http://dx.doi.org/10.1016/0016-5085(95)90192-2. PMid:7698613.

GIBSON, G.R. and ROBERFROID, M.B., 1995. Dietary modulation of the human colonic microbiota: introducing the concept of prebiotics. The Journal of Nutrition, vol. 125, no. 6, pp. 14011412. http://dx.doi.org/10.1093/jn/125.6.1401. PMid:7782892.

HUGENHOLTZ, J. and SMID, E.J., 2002. Nutraceutical production with food-grade microorganisms. Current Opinion in Biotechnology, vol. 13, no. 5, pp. 497-507. http://dx.doi.org/10.1016/S09581669(02)00367-1. PMid:12459344.
IRAPORDA, C., RUBEL, I.A., MANRIQUE, G.D. and ABRAHAM, A.G., 2019. Influence of inulin rich carbohydrates from Jerusalem artichoke (Helianthus tuberosus L.) tubers on probiotic properties of Lactobacillus strains. LWT, vol. 101, pp. 738-746. http://dx.doi. org/10.1016/j.lwt.2018.11.074.

KANDLER, O., 1983. Carbohydrate metabolism in lactic acid bacteria. Antonie van Leeuwenhoek, vol. 49, no. 3, pp. 209-224. http:// dx.doi.org/10.1007/BF00399499. PMid:6354079.

KANJAN, P. and HONGPATTARAKERE, T., 2017. Prebiotic efficacy and mechanism of inulin combined with inulin-degrading Lactobacillus paracasei I321 in competition with Salmonella. Carbohydrate Polymers, vol. 169, pp. 236-244. http://dx.doi. org/10.1016/j.carbpol.2017.03.072. PMid:28504142.

KLEWICKI, R. and KLEWICKA, E., 2004. Antagonistic activity of lactic acid bacteria as probiotics against selected bacteria of the Enterobaceriacae family in the presence of polyols and their galactosyl derivatives. Biotechnology Letters, vol. 26, no. 4, pp. 317320. http://dx.doi.org/10.1023/B:BILE.0000015450.59100.60. PMid: 15055768.

LA ROSA, M., BOTTARO, G., GULINO, N., GAMBUZZA, F., DI FORTI, F., INI, G. and TORNAMBÈ, E., 2003. Prevention of antibioticassociated diarrhea with Lactobacillus sporogens and fructooligosaccharides in children: a multicentric double-blind vs placebo study. Minerva Pediatrica, vol. 55, no. 5, pp. 447-452. PMid:14608267.

LAAL-KARGAR, N., DOLATABADI, S. and MOHTASHAMI, M., 2020. Antibacterial and antibiofilm effects of synbiotics against multidrug-resistant bacteria: acinetobacter baumannii and Enterococcus faecalis. Annals of Clinical Microbiology and Antimicrobials. In press.

LEE, Y.-K. and SALMINEN, S., 1995. The coming of age of probiotics. Trends in Food Science \& Technology, vol. 6, no. 7, pp. 241-245. http://dx.doi.org/10.1016/S0924-2244(00)89085-8.

LIKOTRAFITI, E., VALAVANI, P., ARGIRIOU, A. and RHOADES, J., 2015. In vitro evaluation of potential antimicrobial synbiotics using Lactobacillus kefiri isolated from kefir grains. International Dairy Journal, vol. 45, pp. 23-30. http://dx.doi.org/10.1016/j. idairyj.2015.01.013.

MAFTEI, N.-M., 2019. Probiotic, prebiotic and synbiotic products in human health. In: R.L. SOLÍS-OVIEDO and A. C. PECH-CANUL, eds. Frontiers and new trends in the science of fermented food and beverages. London: IntechOpen. http://dx.doi.org/10.5772/ intechopen.81553.

MANDERSON, K., PINART, M., TUOHY, K.M., GRACE, W.E., HOTCHKISS, A.T., WIDMER, W., YADHAV, M.P., GIBSON, G.R. and RASTALL, R.A., 2005. In vitro determination of prebiotic properties of oligosaccharides derived from an orange juice manufacturing by-product stream. Applied and Environmental Microbiology, vol. 71, no. 12, pp. 8383-8389. http://dx.doi.org/10.1128/ AEM.71.12.8383-8389.2005. PMid:16332825.

MANNING, T.S. and GIBSON, G.R., 2004. Microbial-gut interactions in health and disease: prebiotics. Best Practice \& Research. Clinical Gastroenterology, vol. 18, no. 2, pp. 287-298. http:// dx.doi.org/10.1016/j.bpg.2003.10.008. PMid:15123070.

MARTINS, M.L., MOURIÑO, J.L.P., FEZER, G.F., BUGLIONE NETO, C.C., GARCIA, P., SILVA, B.C., JATOBÁ, A. and VIEIRA, F.N., 2010. Isolation and experimental infection with Vibrio alginolyticus in the sea horse, Hippocampus reidi Ginsburg, 1933 (Osteichthyes: Syngnathidae) in Brazil. Brazilian Journal of Biology = Revista Brasileira de Biologia, vol. 70, no. 1, pp. 205-209. http://dx.doi. org/10.1590/S1519-69842010000100028. PMid:20231979.

MCLAUGHLIN, H.P., MOTHERWAY, M.O., LAKSHMINARAYANAN, B., STANTON, C., ROSS, R.P., BRULC, J., MENON, R., O'TOOLE, P.W. 
and VAN SINDEREN, D., 2015. Carbohydrate catabolic diversity of bifidobacteria and lactobacilli of human origin. International Journal of Food Microbiology, vol. 203, pp. 109-121. http:// dx.doi.org/10.1016/j.ijfoodmicro.2015.03.008. PMid:25817019.

MOROVIC, W. and BUDINOFF, C.R., 2021. Epigenetics: a new frontier in probiotic research. Trends in Microbiology, vol. 29, no. 2, pp. 117-126. http://dx.doi.org/10.1016/j.tim.2020.04.008. PMid:32409146.

ÖNAL DARILMAZ, D., SÖNMEZ, Ş. and BEYATLI, Y., 2019. The effects of inulin as a prebiotic supplement and the synbiotic interactions of probiotics to improve oxalate degrading activity. International Journal of Food Science \& Technology, vol. 54, no. 1, pp. 121-131. http://dx.doi.org/10.1111/ijfs.13912.

PAN, X., WU, T., ZHANG, L., CAI, L. and SONG, Z., 2009. Influence of oligosaccharides on the growth and tolerance capacity of lactobacilli to simulated stress environment. Letters in Applied Microbiology, vol. 48, no. 3, pp. 362-367. http://dx.doi. org/10.1111/j.1472-765X.2008.02539.x. PMid:19187509.

PIATEK, J., KRAUSS, H., CIECHELSKA-RYBARCZYK, A., BERNATEK, M., WOJTYLA-BUCIORA, P. and SOMMERMEYER, H., 2020. InVitro Growth Inhibition of Bacterial Pathogens by Probiotics and a Synbiotic: Product Composition Matters. International Journal of Environmental Research and Public Health, vol. 17, no. 9, pp. 3332. http://dx.doi.org/10.3390/ijerph17093332. PMid:32403297.

PIATEK, J., SOMMERMEYER, H., CIECHELSKA-RYBARCZYK, A. and BERNATEK, M., 2019. In-vitro pathogen inhibition: comparing the inhibitory effects of a complex multistrain synbiotic with simple probiotics containing the yeast Saccharomyces boulardii or Lactobacillus rhamnosus bacteria. bioRxiv. In press.

ROBERFROID, M.B., 2001. Prebiotics: preferential substrates for specific germs? The American Journal of Clinical Nutrition, vol. 73, no. 2, suppl., pp. 406s-409s. http://dx.doi.org/10.1093/ ajcn/73.2.406s. PMid:11157349.

ROWLAND, I.R., RUMNEY, C.J., COUTTS, J.T. and LIEVENSE, L.C., 1998. Effect of Bifidobacterium longum and inulin on gut bacterial metabolism and carcinogen-induced aberrant crypt foci in rats. Carcinogenesis, vol. 19, no. 2, pp. 281-285. http://dx.doi. org/10.1093/carcin/19.2.281. PMid:9498277.

SHAHZAD, M.M., BUTT, W., HUSSAIN, Z., REHMAN, R.A., KHAN, M.K.A., HUSSAIN, M., NOUREEN, A., BASHIR, S., TARIQ M., RAFIQUE, M.T., KHALID, F., RASHID, H., AKHTAR, K. and TAHIR, L., 2023. Use of multi-strain probiotics in linseed meal based diet for Labeo rohita fingerlings. Brazilian Journal of Biology = Revista Brasileira de Biologia, vol. 83, pp. e246727. http://dx.doi. org/10.1590/1519-6984.246727. PMid:34468521.

SIMS, M.D., DAWSON, K.A., NEWMAN, K.E., SPRING, P. and HOOGELL, D.M., 2004. Effects of dietary mannan oligosaccharide, bacitracin methylene disalicylate, or both on the live performance and intestinal microbiology of turkeys. Poultry Science, vol. 83, no. 7, pp. 1148-1154. http://dx.doi.org/10.1093/ps/83.7.1148. PMid:15285506.

ŚLIŻEWSKA, K. and CHLEBICZ-WÓJCIK, A., 2020. The in vitro analysis of prebiotics to be used as a component of a synbiotic preparation. Nutrients, vol. 12, no. 5, pp. 1272. http://dx.doi. org/10.3390/nu12051272. PMid:32365804.

SPRING, P., WENK, C., DAWSON, K.A. and NEWMAN, K.E., 2000. The effects of dietary mannaoligosaccharides on cecal parameters and the concentrations of enteric bacteria in the ceca of salmonella-challenged broiler chicks. Poultry Science, vol. 79, no. 2, pp. 205-211. http://dx.doi.org/10.1093/ps/79.2.205. PMid:10735748.

STEFANIA, D.M., MIRANDA, P., DIANA, M., CLAUDIA, Z., RITA, P. and DONATELLA, P., 2017. Antibiofilm and antiadhesive activities of different synbiotics. Journal of Probiotics and Health, vol. 5, no. 3, pp. 182-191. http://dx.doi. org/10.4172/2329-8901.1000182.

TULUMOĞLU, Ş., ERDEM, B. and ŞIMŞEK, Ö., 2018. The effects of inulin and fructo-oligosaccharide on the probiotic properties of Lactobacillus spp. isolated from human milk. Zeitschrift für Naturforschung C, vol. 73, no. 9-10, pp. 367-373. http://dx.doi. org/10.1515/znc-2018-0001. PMid:29787377.

VANDENBERGH, P.A., 1993. Lactic acid bacteria, their metabolic products and interference with microbial growth. FEMS Microbiology Reviews, vol. 12, no. 1-3, pp. 221-237. http:// dx.doi.org/10.1111/j.1574-6976.1993.tb00020.x.

WANG, X. and GIBSON, G.R., 1993. Effects of the in vitro fermentation of oligofructose and inulin by bacteria growing in the human large intestine. The Journal of Applied Bacteriology, vol. 75, no. 4, pp. 373-380. http://dx.doi.org/10.1111/j.1365-2672.1993. tb02790.x. PMid:8226394.

WATSON, D., O'CONNELL MOTHERWAY, M., SCHOTERMAN, M.H.C., VAN NEERVEN, R.J., NAUTA, A. and VAN SINDEREN, D., 2013. Selective carbohydrate utilization by lactobacilli and bifidobacteria. Journal of Applied Microbiology, vol. 114, no. 4, pp. 1132-1146. http://dx.doi.org/10.1111/jam.12105. PMid:23240984.

WONGKRASANT, P., PONGKORPSAKOL, P., ARIYADAMRONGKWAN, J., MEESOMBOON, R., SATITSRI, S., PICHYANGKURA, R., BARRETT, K.E. and MUANPRASAT, C., 2020. A prebiotic fructooligosaccharide promotes tight junction assembly in intestinal epithelial cells via an AMPK-dependent pathway. Biomedicine and Pharmacotherapy, vol. 129, pp. 110415. http://dx.doi. org/10.1016/j.biopha.2020.110415. PMid:32603892.

ZHANG, Z., KHATUN, M.S. and O'HARA, I. 2021. Production of fructo-oligosaccharide as valuable feed prebiotics from lowvalue molasses: a review. In: Proceedings of the 42nd Australian Society of Sugar Cane Technologists Conference (ASSCT), 2021, Bundaberg, Australia. Queensland: Australian Society of Sugar Cane Technologists (ASSCT), pp. 107-112. 